\title{
An rpoB signature sequence provides unique resolution for the molecular typing of cyanobacteria
}

\author{
Correspondence \\ Virginie Gaget \\ virginie.gaget@sawater.com.au
}

\author{
Virginie Gaget, ${ }^{1 \dagger}$ Simonetta Gribaldo ${ }^{2}$ and Nicole Tandeau de Marsac ${ }^{1 \ddagger}$ \\ ${ }^{1}$ Institut Pasteur, Unité des Cyanobactéries; URA CNRS 2172, 75015 Paris, France \\ ${ }^{2}$ Institut Pasteur, Unité de Biologie Moléculaire du Gène Chez les Extrêmophiles; 75015, Paris, \\ France
}

\section{INTRODUCTION}

Cyanobacteria represent a monophyletic group of oxygenic photosynthetic bacteria within the Eubacteria. Since their appearance between 2.45 and 2.32 billion years ago (Rasmussen et al., 2008), the cyanobacteria have developed a number of adaptive strategies and thus form a very diverse group of prokaryotes. Their classification has been established based on morphological and physiological criteria under the International Code of Botanical Nomenclature (ICBN) (Greuter et al., 2000). In 1978, having recognized their truly prokaryotic nature, Stanier et al. (1978) proposed that their nomenclature be governed by the provisions of the International Code of Nomenclature of Bacteria (ICNB) (Lapage et al., 1992). Although efforts to harmonize the use of both Codes and to achieve a consensus nomenclature have been made over the past 25 years to further integrate cyanobacteria into the Bacteriological code, the names of only a very limited number of taxa have been validly published under the

tPresent address: United Water, 180 Greenhill Road, 5063 Parkside, SA, Australia.

łPresent address: Laboratoire de Chimie Bactérienne, UPR CNRS 9043, Université d'Aix-Marseille, 13402 Marseille cedex 20, France.

Abbreviations: ML, maximum-likelihood; MP, maximum-parsimony; $\mathrm{NJ}$, neighbour-joining.

Supplementary data are available with the online version of this paper.
Bacteriological Code (Trüper, 1986; Oren, 2004). This dual nomenclature has resulted in the use of multiple names for the same organism, causing considerable confusion in the literature. Therefore, cyanobacterial taxonomy and strain assignment still remains an important issue in the scientific community.

Since the development of molecular biology methods, the taxonomy of many bacterial taxa has been challenged, and the morphological traits employed for the description of cyanobacteria are not sufficient to unambiguously identify or describe a new isolate, resulting in a classification that is not always phylogenetically coherent (Honda et al., 1999; Ishida et al., 2001; Wilmotte \& Herdman, 2001). On the other hand, sequence analysis of the $16 \mathrm{~S}$ rRNA gene, largely used to establish the phylogenetic relationships among cyanobacteria, has only in some cases led to the description of phylogenetically coherent taxa (Giovannoni et al., 1988; Turner et al., 1999; Wilmotte \& Herdman, 2001). Therefore, additional genetic markers, used alone or in combination with morphological criteria, are often necessary to resolve some specific nodes or taxa (Rajaniemi et al., 2005; Suda et al., 2002; Tanabe et al., 2007).

The gene encoding the RNA polymerase $\beta$ subunit $(r p o B)$ has been shown to be a reliable genetic marker for phylogenetic analyses for many bacterial phyla (Case et al., 2007; Hong et al., 2004; Salerno et al., 2007; Volokhov et al., 2007). Interestingly, an indel (insertion/ 
deletion) was noticed in the $r p o B$ sequences of Nostocaceae, but was not discussed further (Rajaniemi et al., 2005). Indels have been used as phylogenetic characters to assess evolutionary relationships among many bacterial and archaeal phyla (Gupta, 1997, 1998) and recently among cyanobacterial taxa (Gupta, 2003, 2009). However, as indels often correspond to protein loops, they can easily be lost independently in evolutionarily unrelated sequences and thus give rise to misleading convergences. This phenomenon of convergence limits the use of indels for the investigation of large-scale evolutionary relationships. However, in combination with molecular phylogenies, indels may resolve some specific nodes, and also may be useful for sequence comparisons at a genus or species level.

In the present study, we sequenced part of the $r p o B$ gene from different strains of cyanobacteria belonging to the genus Oscillatoria and investigated the presence and distribution of a specific signature (including an indel) in their RpoB sequences, as well as in publicly available RpoB sequences from 118 additional cyanobacterial strains. Comparative analyses of the amino acid sequences of these signatures reveal that they might be a very useful tool for cyanobacterial screening and assignment at a subgenus level.

\section{METHODS}

Strains and culture conditions. The 16 Planktothrix and Oscillatoria strains used in this study (indicated in bold in Supplementary Table S1, available with the online version of this paper) were supplied by the Pasteur Culture Collection of Cyanobacteria (PCC). All strains were incubated at $25{ }^{\circ} \mathrm{C}$ under white light (Osram Universal White) with a photosynthetic photon flux density (PPFD) of $30 \mu \mathrm{mol}$ quanta $\mathrm{m}^{-2} \mathrm{~s}^{-1}$ (measured with a LICOR LI-185B quantum/radiometer/photometer equipped with a LI-190SB quantum sensor). All strains were maintained in liquid BG11 medium (Rippka, 1988) containing $0.4 \mathrm{mM} \mathrm{Na} \mathrm{CO}_{3}$, except strains PCC 10106 and PCC 10110, for which the concentration of $\mathrm{NaNO}_{3}$ in the BG-11 medium was reduced to $2 \mathrm{mM}$.

DNA extraction, amplification and sequencing. Aliquots $(2 \mathrm{ml})$ of liquid cultures were centrifuged at $12000 \mathrm{~g}$ for $10 \mathrm{~min}$ at $20{ }^{\circ} \mathrm{C}$ and washed twice with sterile MilliQ water. The final pellets were resuspended in $200 \mu \mathrm{l}$ sterile MilliQ water and frozen in liquid nitrogen. Lysates of the frozen samples were prepared by a minimum of ten alternating cycles of thawing at $100{ }^{\circ} \mathrm{C}$ for $5 \mathrm{~min}$ and refreezing in liquid nitrogen. For Planktothrix and Oscillatoria strains, specific primers RPObF1 (5'-AGGAATTCACCACCACAACT-3') and RPObR1 (5'-ACCATCGGCTAATACCTG-3') were designed to amplify a $600 \mathrm{bp}$ region. For the $16 \mathrm{~S}$ rRNA total amplification, the forward primer A2 (5'-AGAGTTTGATCCTGGCTCAG-3'; Iteman et al., 2002) and the 16SR1 primer (5'-GGTCTCCCTAAAAGGAGGTG-3') located respectively at the beginning of the $16 \mathrm{~S}$ rRNA and in the internal transcribed spacer (ITS) were used. The DNA sequences used for primer design were collected from the NCBI (National Center for Biotechnology Information) database (www.ncbi.nlm.nih. gov). New primers were designed with Primer 3 v.0.4.0 (http://frodo. wi.mit.edu/) using the sequences of Planktothrix sp. NIVA-CYA 126 and NIVA-CYA 127 (AJ628133, AJ783334). The PCR mixtures, in a final volume of $50 \mu \mathrm{l}$, contained $5 \mu \mathrm{l}$ lysate, $5 \mu \mathrm{l} 10 \times$ PCR buffer, $1.5 \mu \mathrm{l} 50 \mathrm{mM} \mathrm{MgCl}_{2}, 1.5 \mu \mathrm{l} 2.5 \mathrm{mM}$ deoxyribonucleotides mix,
$1.25 \mu \mathrm{l}$ each primer diluted to $0.1 \mu \mathrm{g} \mu \mathrm{l}^{-1}$ (MWG Biotech) and $5 \mu \mathrm{l}$ $5 \mathrm{U}$ Taq DNA polymerase $\mu \mathrm{l}^{-1}$ (Invitrogen). After an initial step consisting of $5 \mathrm{~min}$ at $95{ }^{\circ} \mathrm{C}, 35$ cycles of amplification were performed; each amplification cycle consisting of $30 \mathrm{~s}$ at $95{ }^{\circ} \mathrm{C}, 30 \mathrm{~s}$ at $52{ }^{\circ} \mathrm{C}$ and $1 \mathrm{~min}$ at $72{ }^{\circ} \mathrm{C}$. A final elongation step was carried out for $5 \mathrm{~min}$ at $72{ }^{\circ} \mathrm{C}$. All DNA amplifications were performed in a GeneAmp PCR System 9700 thermocycler (Applied Biosystems). A total of $10 \mu \mathrm{l}$ of each sample was analysed by electrophoresis on $2 \%$ $(\mathrm{w} / \mathrm{v})$ agarose (Litex FMC) gels $(200 \mathrm{ml})$ in $1 \times$ Tris-borate/EDTA

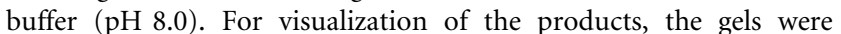
stained with $200 \mu \mathrm{l}$ ethidium bromide $\left(0.7 \mu \mathrm{g} \mathrm{ml}^{-1}\right)$. After amplification, fragments of interest were sent to MWG Biotech for sequencing using cycle sequencing technology (dideoxy chain termination/cycle sequencing) on ABI 3730XL sequencing machines.

Sequence retrieval and alignment. Except for the sequences of the 16 strains established in the present study, the $r p o B$ and $16 \mathrm{~S}$ rRNA gene sequences of 118 other cyanobacterial strains were retrieved from the NCBI database (Table S1). Both the nucleotide sequences and their corresponding amino acid sequences were aligned with CLUSTAL_X v.1.83 (Jeanmougin et al., 1998). Multiple alignments were edited with GeneDoc v.2.6.002 (Nicholas et al., 1997) and ambiguously aligned positions were removed using Gblocks v.0.91b with default parameters (Castresana, 2000)

Phylogenetic analyses. Phylogenetic trees were calculated on nucleotide alignments by using three methods: neighbour-joining (NJ), maximum-parsimony (MP) and maximum-likelihood (ML). NJ (Jukes-Cantor model) and MP trees were calculated by using MEGA4 (Tamura et al., 2007). ML trees were computed with Phyml v.2.4.1 (Guindon \& Gascuel, 2003) and the HKY (HasegawaKishino-Yano) model of nucleotide substitution (Hasegawa et al., 1985 ) using one category of substitution rate. For each method, the robustness of each branch was estimated by non-parametric bootstrap analysis (100 replicates) using the two programs cited above. Sequences from strains of each monophyletic group were extracted from the general alignment, and sequences of strains among this group were independently realigned, giving a new tree. This operation was repeated until there was no further resolution in the resulting tree. These consecutive trees are called tier trees in this study.

Signature sequence localization. The position of the indel within the $r p o B$ gene was visualized using SMART (http://smart.emblheidelberg.de/). The position of the indel and its impact on the three-dimensional structure of the $\beta$ subunit of RNA polymerase were evaluated by aligning the $r p o B$ sequences of Synechocystis sp. strain PCC 6803 (NC000911) and Anabaena/Nostoc sp. strain PCC 7120 (BA000019) with the sequence of Thermus thermophilus (YP_145079.1), for which the RNA polymerase structure has been crystallized (2GHO) (Kuznedelov et al., 2002), by using RASWIN Molecular Graphics v.2.6 (Sayle \& Milner-White, 1995).

\section{RESULTS AND DISCUSSION}

\section{Characterization of the indel within the rpoB gene}

As described in Table S1, the PCR amplicons obtained for 12 of the 16 strains tested were 453 bp long, while shorter products, $351 \mathrm{bp}$ long, were obtained for the four remaining strains: Planktothrix agardhii PCC 9214 and Oscillatoria sp. strains PCC 8926, PCC 8954 and PCC 9631. A multiple alignment showed that the longer $r p o B$ sequences display an indel of $120 \mathrm{nt}$ and the shorter an indel of $18 \mathrm{nt}$. The sequence of the inserts in the longer 
(a)

and

Thermosynechococcus

Filamentous non-heterocystous cyanobacteria
ผH7803_Synechococcus_sp FCC9311_Synechococcus_sp MIT9303_Frochlorococcus_rarinu MIT9313_Erochlorococcus_rarinu RCC307_Synechococcus_sp MIT9301_Frochlorococcus_rarinu AS9601_Frochlorococcug_rrarinug CCMF1986_Frochlorococcus_rarin MIT9515_Frochlorococcus_rarinu MIT9312_Frochlorococcus_rarinu NATI1A_Frochlorococcug_rarinug NATI2A Frochlorococcus rarinus CCMF1375_Frochlorococcug_rarin ตн8102_Synechococcus_sp CC9605_Synechococcus_gp cC9902_Synechococcus_sp FCC6301_Synechococcus_elongatu FCC7942_Synechococcus_elongatu JA23Ba_Synechococcus_sp JA33AL_Synechococcus_sp BF1_Therrosynechococcus_elonga FCC7 421 Gloeobactex violaceus IMS101_ $\bar{T}$ richodegriur_erythraeu FCC8106_Iyngbya_sp

FCC9637 Flanktothrix agardhii FCC9702_Flanktothrix_agardhii FCC10606_Flanktothrix_rubescen FCC7805_Flanktothrix_agardhis FCC9239_Flanktothrix_agardhii FCC10607_Flanktothrix_agardhii FCC9625_Flanktothrix_agardhii FCC7811 Flanktothrix agardhii FCC10106_Flanktothrix_rubescen FCC9801_Elanktothrix_agardhii FCC10110_Flanktothrix_agardhii FCC7821 Flanktothrix rubegcens NIVACYA127_Flanktothrix_gp FCC8927_Cscillatoria_sp ECC9018_Cgcillatoria gp NIVACYA126_FlanktFthrix_agardh FCC8926_Cgcillatoria_sp FCC8954 Cscillatoria gp FCC9631_Cscillatoria_sp FCC9214_Flanktothrix_sp FCC9350_Nodularia_spurigena HEM_Nodularia_spurigena Huebel1987310_Nodularia_spurig NSCR12_Nodularia_Spu

I81 Nodularia spurigena Huebel1988306_Nodularia_spurig GRBb_Nodularia_spurigena ECC7804_Nodularia_sphaerocarpa HKVV_Nodularia_sphaerocarpa ECC73104_1_Nodularia_spurigena Up16a_Nodularia_sphaerocarpa Up16f_Nodularia_sphaerocarpa UTEXB2092_Nodularia_harveyana BECIC35_Nodularia_sphaerocarpa Eae19_Nodularia_spurigena BECIC2̄﹎_Nodularia_harveyana BECIL2?_Nodularia_harveyana Bo53 Noōulariaharv

BECI $\bar{L} 36$ Nodularia_sphaerocarpa Huebel1983300_Nodularia_harvey NSFI05_Nodularia_spurigena AV63_Nodularia_spurigena Hbl1987_311_Nodularia_spurigen AV1_Nodularia_spurigena BY1_Nodularia_spurigena
Indel location

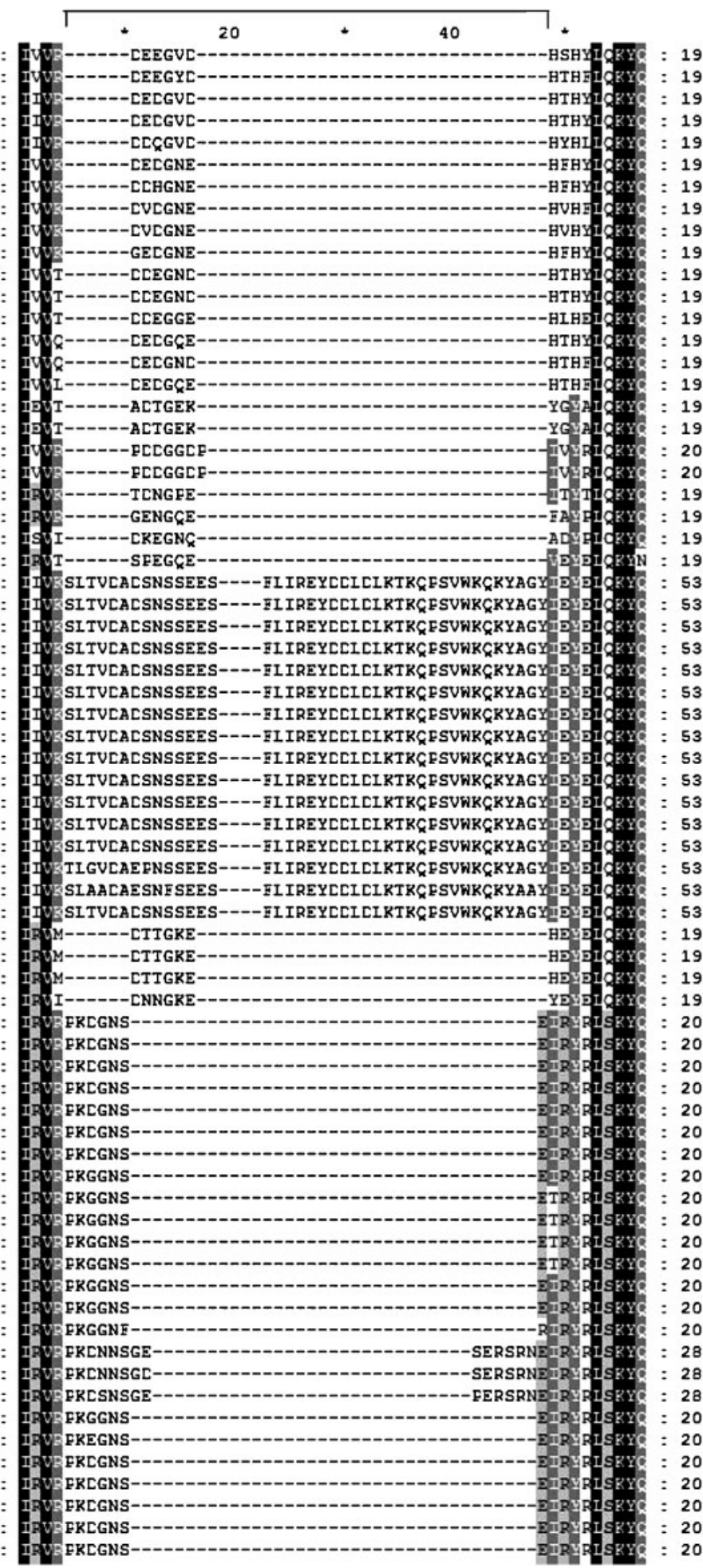

Fig. 1. Alignment of amino acid sequences corresponding to the rpoB gene region that contains an indel. The $r p o B$ gene sequences available in public databases were selected and their corresponding amino acid sequences were aligned with the sequences from 16 Planktothrix and Oscillatoria strains obtained in this study, and the Escherichia coli K-12 sequence. The different cyanobacterial genera and strain identifiers are indicated on the left. The darker the highlighting of the amino acid, the more conserved it is in all the aligned sequences. 
(b)

Anabaena

Aphanizomenon

Trichormus
ANA281AR_Anabaena_circinalis FCC7108_Anabaena_sp

BCHINCAR 198443 Añabaena_ogcill SJ4a_Anabaena_augugtana 0tu3797_Aphanizorenon_iggatgch ANA227_Anabaena_flog_aquae

277 Anabaena ge

1tu $\overline{3} 698$ 8nabaena_planctonica 1tu3595_Anabaena_rucosa 1tu39917_Anabaena_spiroideg Otu3894_Anabaena_sigroida 0tu3697_Anabaena_sigroida ANA118A_Anabaena_circinalis ANA150A Anabaena circinalis ANA175A Anabaena circinalig ANA049A_Anabaena_circinalig ANA301AR_Anabaena_circinalig ANA349H Anabaena circinalig ANA337A_Anabaena_solitaria ANA148_Anabaena_circinalig ANA059A_Anabaena_circinalig 1 tu3398 Anabaena_planctonica 1 tu2898_Anabaena_planctonica 1tu33910_Anabaena_planctonica 1tu27g7_Anabaena_cragga 1 tu33g12 Anabaena circinalis 1tu30s11_Anabaena_circinalig 1tu30s13_Anabaena_planctonica 1 tu 3497 Anabaena sp

1tu2692_Aphanizorrenon_flog_aqu 1tu29919_Aphanizorenon_flog_aq 1tu37g13_Aphanizorenon_flog_aq 1 tu39g8 Anabaena grithi $\bar{i}$

1 tu35s12 Anabaenáflog_aquae 90 Anabaena_circiñalis 1tu32g11_Anabaena_lerrerranii 1 tu 3094 Anabaena flog aquae 1tu31g11 Anabaena_flog_aquae 66A_Anabaena_lerrierranii ANACCMRCR_Anabaena_corpacta 1tu26910 Anabaena circinalis_r 1tu2795_Anabaena_circinalig_zra 1 tu28s13_Anabaena_circinalis_n 14 Anabaena flog_aquae

TR183 Aphanizorenon flog aquae FCC7905_Aphanizorenon_flog_aqu 202_Aphanizorenon_sp

0tu2596 Anabaena_circinalig ra 1tu26916 Aphanizorenon gracile HEANEYCarrb198614011_Aphanizorre 1tu23g3_Anabaena_circinalig_ra 0tu3997 Anabaena sp

0tu3799 Anabaena ge

0tu3392a_Anabaena_flog_aquae Otu33.15 Anabaena flog_aquae 1 tu3495 Anabaena circinalig BECIL32_Anabaena_oscillarioide BECIL22_Anabaena_ogcillarioide XF6B_Anabaena_cylindrica ATCC29413 Anabaena variabilis FCC7120_Nostoc_sp ANA062_Anabaena_sp HINCAK2̄0014_Trichorrug_variabi GREIFSWALC Trichorrug variabil Trichorrus_dololiur RorBAI1983_Trichorrug_azollae $\checkmark$ Nogtoc_ellipgosporur

1 tu1498_Nostoc_sp

$\mathrm{X}_{\mathbf{H}}$ Nostoc_edaphicur VI_Nostoc_calcicola III Nogtoc calcicola II_Nogtoc_rugcorur I_Nogtoc_Eugcorur 152_Nogtóc_sp

ECC6803 Synechocystig_sp WH8501_Crocogphaera_watgonii 130_Microcystig_sp NIESB43_Microcystis_aeruginosa FCC7806_Microcystig_aeruginoga 269_Microcystig_sp R12_Escherichia_coli
Indel location

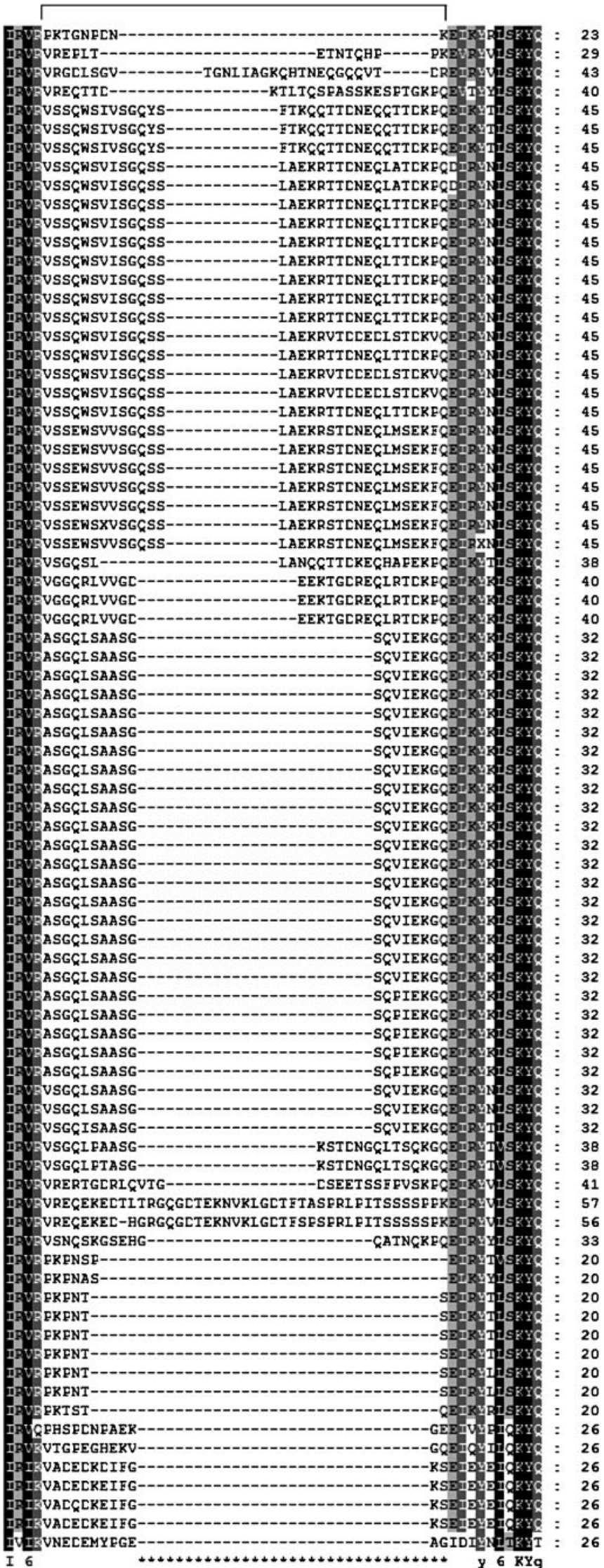


amplicons was used for a BLASTN search (Zhang \& Madden, 1997; Zhang et al., 2000) against the NCBI non-redundant (nr) sequence database. This insert sequence appeared to be highly specific, appearing only in the $r p o B$ gene of the two Planktothrix strains NIVA CYA-126 and NIVA CYA-127.

\section{Signature sequences in the rpoB genes of different cyanobacterial taxa}

To determine if cyanobacterial taxa other than Planktothrix have inserts in their rpoB sequences, all available cyanobacterial $r p o B$ sequence homologues were collected from public databases. A multiple alignment of their corresponding amino acid sequences revealed the existence of a conserved region containing inserts (indels) of lengths varying from 6 to 44 aa (Fig. 1).

The indel is situated in the Rpb2_6 domain of RpoB (determined in the Anabaena/Nostoc sp. strain PCC 7120 sequence) that is involved in DNA binding and DNAdirected RNA polymerase activity (http://smart.emblheidelberg.de/). To locate the insert sequence in the RpoB molecule more precisely, the three-dimensional structure of the Synechocystis sp. strain PCC 6803 and Anabaena/Nostoc sp. strain PCC 7120 RpoB proteins was modelled based on an alignment of their sequences with that of Thermus thermophilus using RASMOL v2.6 (Sayle \&
Milner-White, 1995) (only the RpoB structure of Synechocystis strain PCC 6803 is shown in Supplementary Fig. S1, available with the online version of this paper). This clearly showed that the indel sequence adds an extra loop to a folding region of the Thermus thermophilus consisting of $\beta$ strands. The role of this loop is unknown, but the presence of a few polar amino acids in its sequence indicates that it is unlikely to interact with nucleic acids, thus excluding a direct role in RNA polymerase function. Moreover, no cationic binding sites are apparent. Peptide binding to the loop sequence cannot be excluded but further experiments are required to clarify this assumption.

\section{RpoB signature sequences as a molecular tool for cyanobacterial taxonomy}

To assess the utility of these RpoB sequence signatures as a tool for cyanobacterial taxonomy, we examined if the $r p o B$ gene followed a vertical inheritance or has been exchanged among cyanobacterial strains by horizontal gene transfer. For this, we compared phylogenies (built using three methods: ML, NJ and MP) based on analysis of $16 \mathrm{~S}$ rRNA and $r p o B$ gene sequence phylogenies of the same set of 134 strains. As the length of the $r p o B$ indels is variable depending on the genus (minimum $18 \mathrm{nt}$; maximum $132 \mathrm{nt}$ ), the correction implemented by the Gblocks program removed

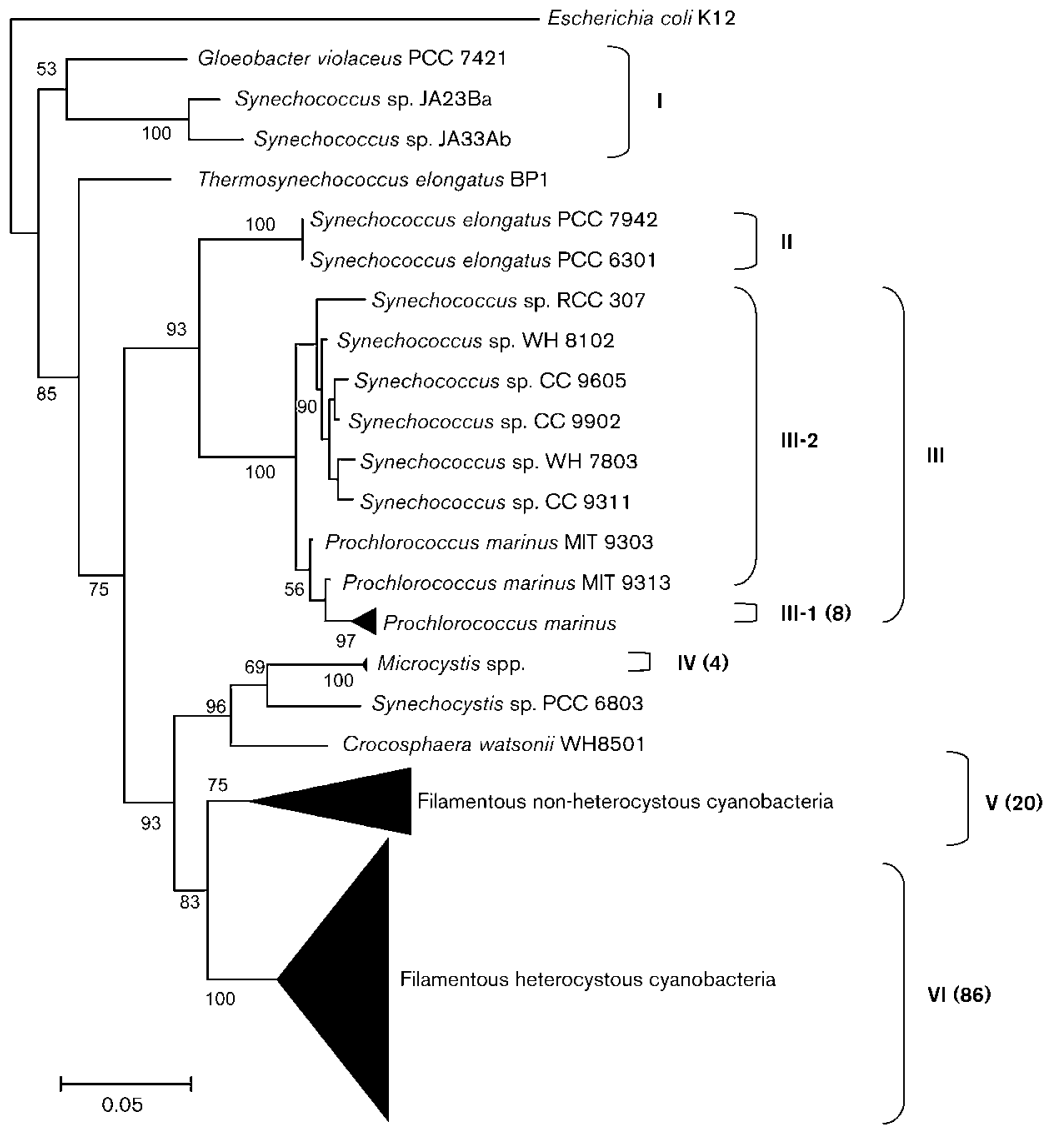

Fig. 2. $\mathrm{ML}$ tree based on $16 \mathrm{~S}$ rRNA gene sequences (1207 nt) from 134 cyanobacterial strains for which an $r p o B$ gene sequence is available. Trees were rooted with the Escherichia coli $\mathrm{K}-12$ rpoB sequence as outgroup. Roman numbers indicate clusters of strains. Black triangles represent groups of related strains; the number in each group is indicated in parentheses. Bootstrap values are shown for each node if $>50 \%$. Bar, 0.05 substitutions per site. 
an important part of the sequence, leaving only $286 \mathrm{nt}$. Consequently, due to the small size of the aligned sequences, the $r p o B$ tree appears less robust than the tree based on $16 \mathrm{~S}$ rRNA gene sequences (data not shown). However, the $r p o B$ tree is largely congruent with the $16 \mathrm{~S}$ tree presented in Fig. 2 (five of the six clusters fully conserved). Moreover, when aligned with the sequences of this $r p o B$ region from other closely related bacterial taxa (data not shown), cyanobacteria form a well-separated group. These two observations show there is no suggestion of obvious horizontal gene transfer, indicating probable vertical inheritance.

Some of the clusters defined in the present study correspond to the clades recently described by Gupta (2009) using distinct indels located in different proteins. Indeed, cluster I identified in this report corresponds to the clade A described by Gupta, while cluster III corresponds to clade C. Group II is an independent node in Gupta (2009) and has not been included in a specific clade.
Strains in clusters IV, V and VI (or on independent nodes for Synechocystis sp. PCC 6803 and Crocosphaera watsonii WH 8501) group differently in clade B (Gupta, 2009), which includes cyanobacteria from various taxa. This inconsistency in the data obtained by the two research groups may be due to a bias introduced by a difference in the number of strains used in the two studies, a higher number being analysed in the present report than in Gupta (2009).

To evaluate the usefulness of the $r p o B$ signatures for molecular typing of cyanobacterial strains, successive trees (hereafter designated tier trees) were constructed for the two clusters (V and VI) inferred from the 16S rRNA genebased tree (Fig. 2) for which the greater numbers of nucleotide sequences (20 and 86 , respectively) were available. Starting from the general $r p o B$ nucleotide alignment, DNA sequences belonging to the same group within clusters $\mathrm{V}$ (groups $\mathrm{V}-1$ and $\mathrm{V}-2$ ) and VI (groups VI-1 and VI-2) were realigned separately and trees were (a)

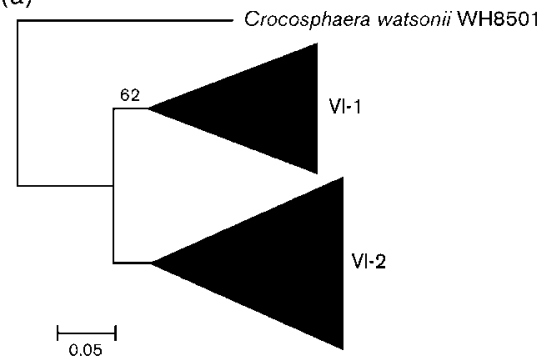

(b)

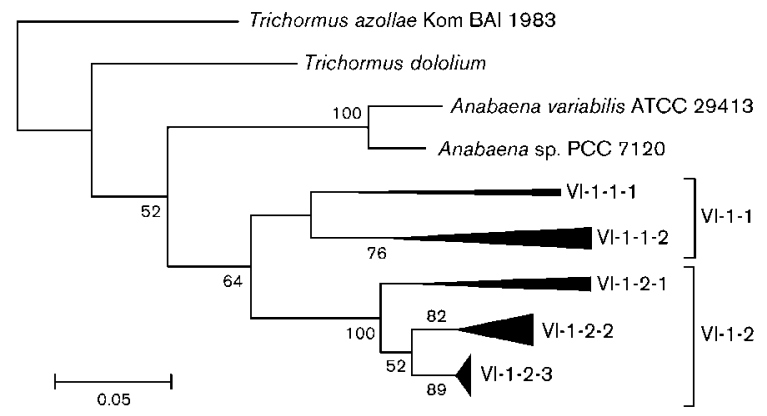

(c)

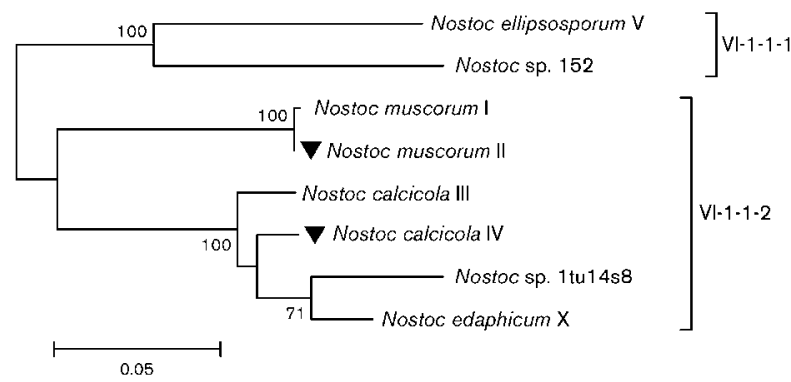

(d)

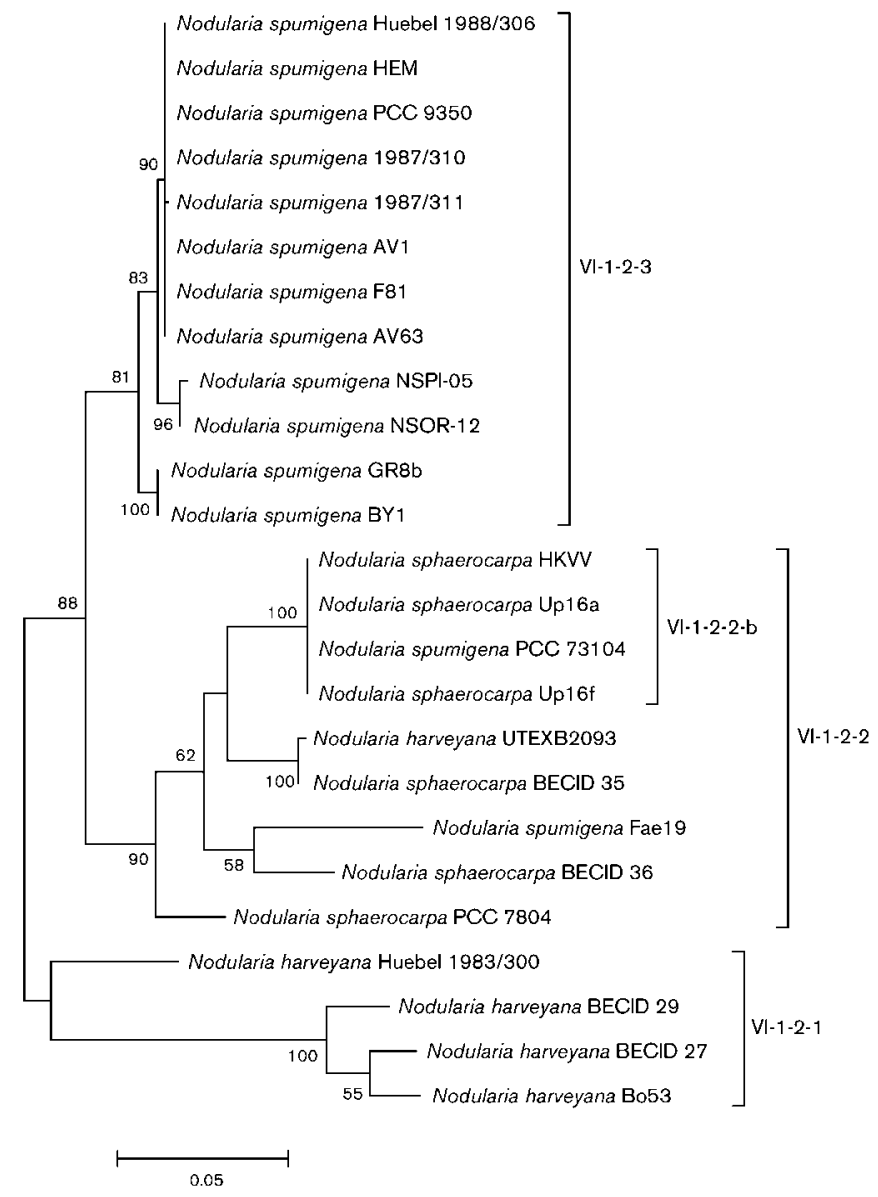

Fig. 3. (a) $M L$ tree based on the $r p o B$ nucleotide sequences of 86 cyanobacterial strains of cluster VI as defined in Fig. 2; (b) 37 strains of group VI-1; (c) Eight strains of subgroup VI-1-1; (d) 25 strains of subgroup VI-1-2. Groups and subgroups correspond to those defined in Table 1. The number of nucleotides used to reconstruct the trees is indicated in parentheses. Bootstrap values are shown for each node if $>50 \%$. Bars, 0.05 substitutions per site. 
constructed (Figs $3 \mathrm{a}$ and $4 \mathrm{a}$ ). This made possible the inclusion of residues that were discarded at the previous level of analysis because of automatic gap removal. The procedure was repeated on each new well-supported subgroup (bootstrap value $>50 \%$ ) until all the sequences realigned possessed exactly the same signature sequence and thus maximal resolution was achieved. For cluster V, the number of nucleotide differences in the sequences being limited, the maximal resolution was obtained after two tier trees were constructed (data not shown), while for cluster VI more tier trees were required (Figs 3 and 4).
Using this approach, we could deduce from the final nucleotide sequences selected 80 distinct specific patterns of RpoB protein signatures and 56 different indels (Table 1) whose clustering is congruent with the groups established using the 16S rRNA gene and rpoB gene sequences. Interestingly, these protein signatures differentiate strains at a subgenus level (Table 1). For example, cluster VI can be divided into two groups (Figs 3a and 4a). Group VI-1 contains members of the genera Nostoc and Nodularia (Fig. 3b, c and d), while the group VI-2 contains members of the genera Anabaena, Aphanizomenon and (a)

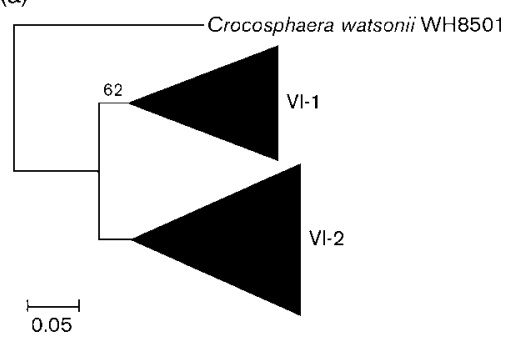

(b)

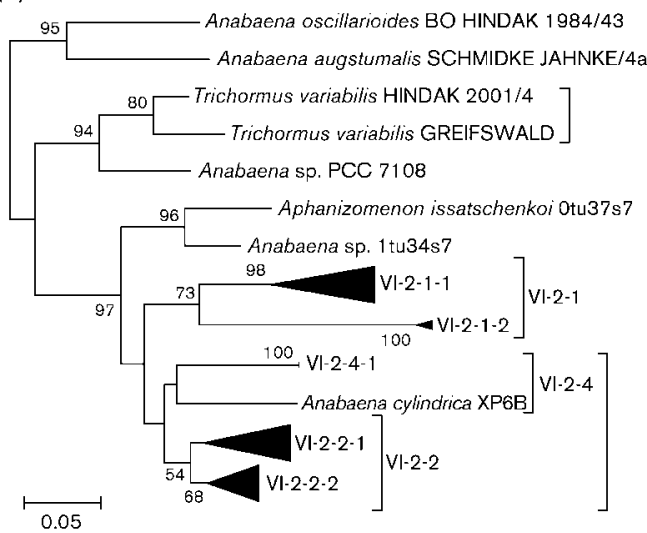

(d)

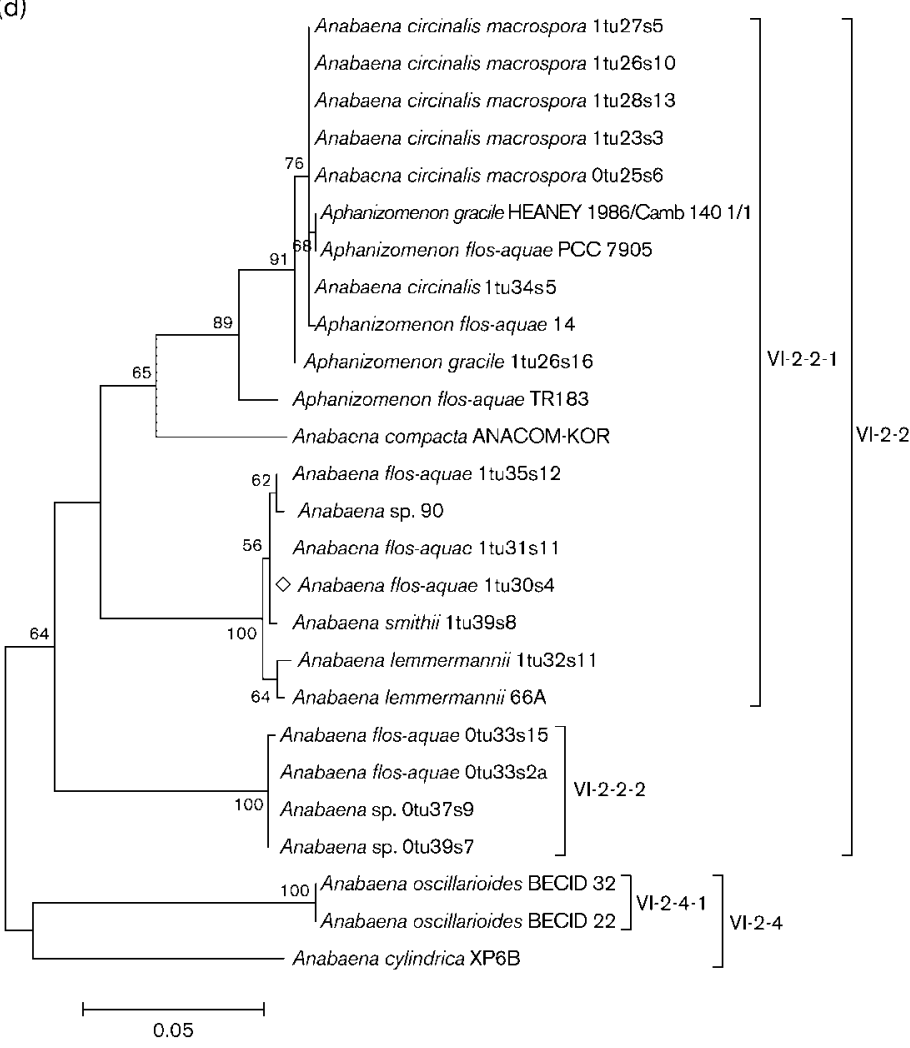

(c)

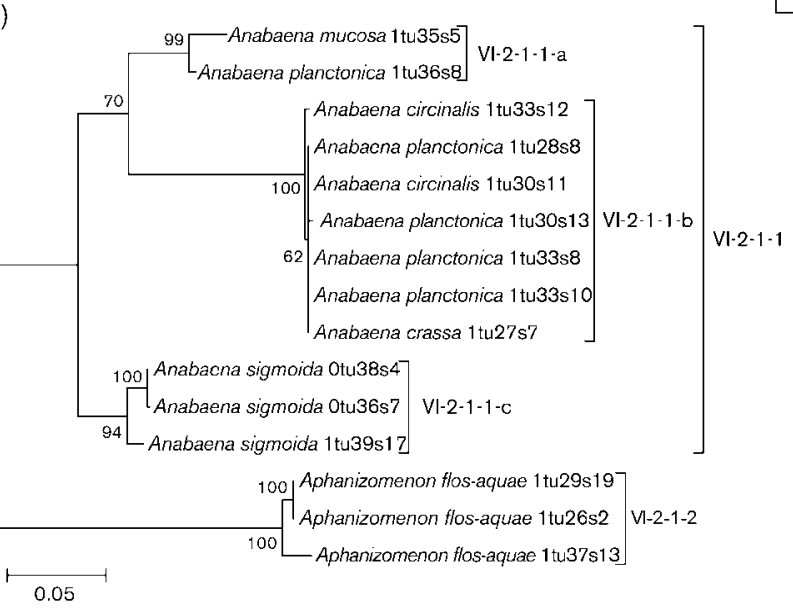

Fig. 4. (a) $M L$ tree based on the $r p o B$ nucleotide sequences of 86 cyanobacterial strains of cluster $\mathrm{VI}$ as defined in Fig. $2 ; 49$ strains of group VI-2 (b); 15 strains of subgroup VI-2-1 (c); 24 strains of subgroup VI-2-2 (d). Groups and subgroups correspond to those defined in Table 1. The number of nucleotides used to reconstruct the trees is indicated in parentheses. Bootstrap values are shown for each node if $>50 \%$. Bars indicate 0.05 substitutions per site. 
Table 1. Patterns of RpoB signature sequences (including indels) in cyanobacteria

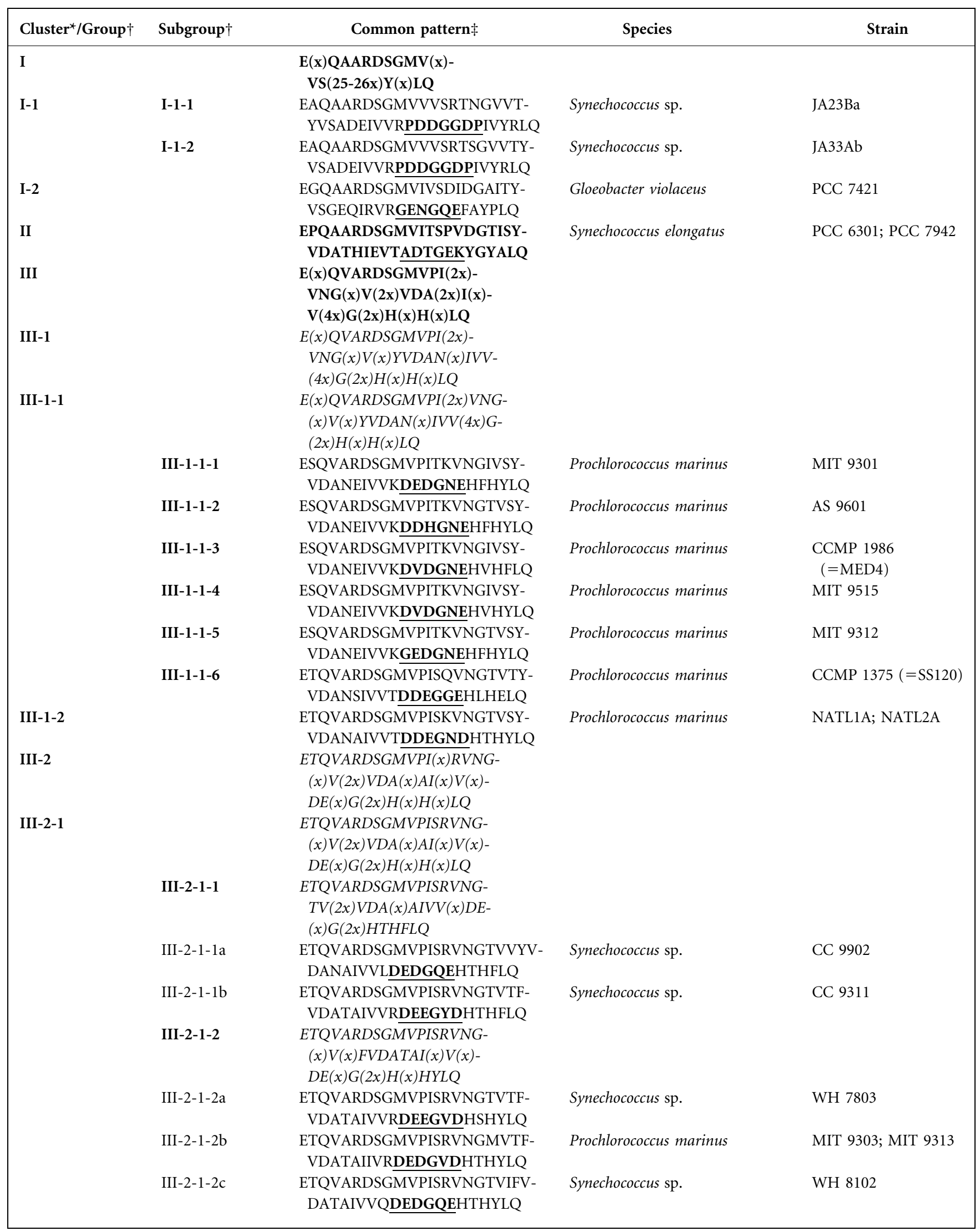


Table 1. cont.

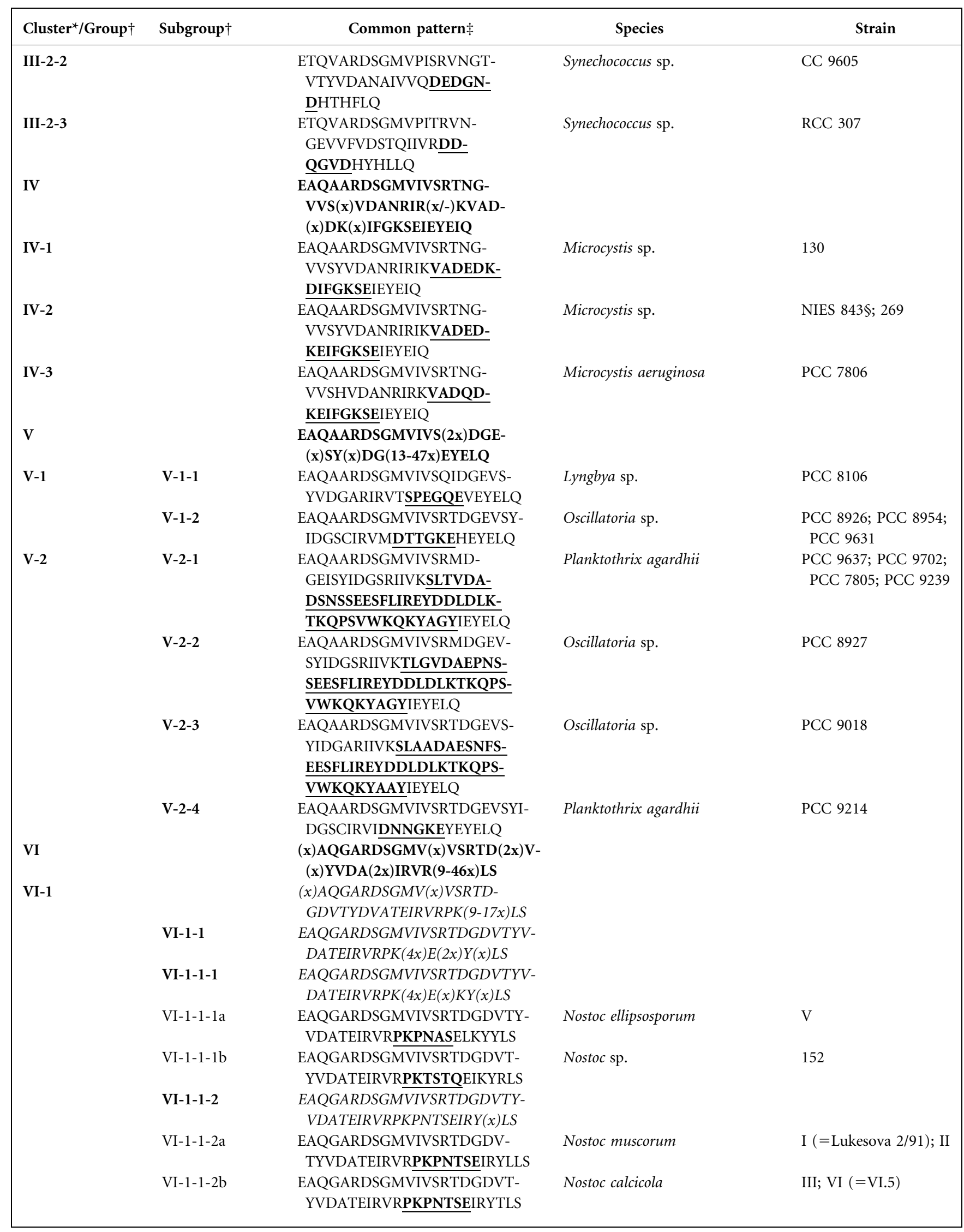


Table 1. cont.

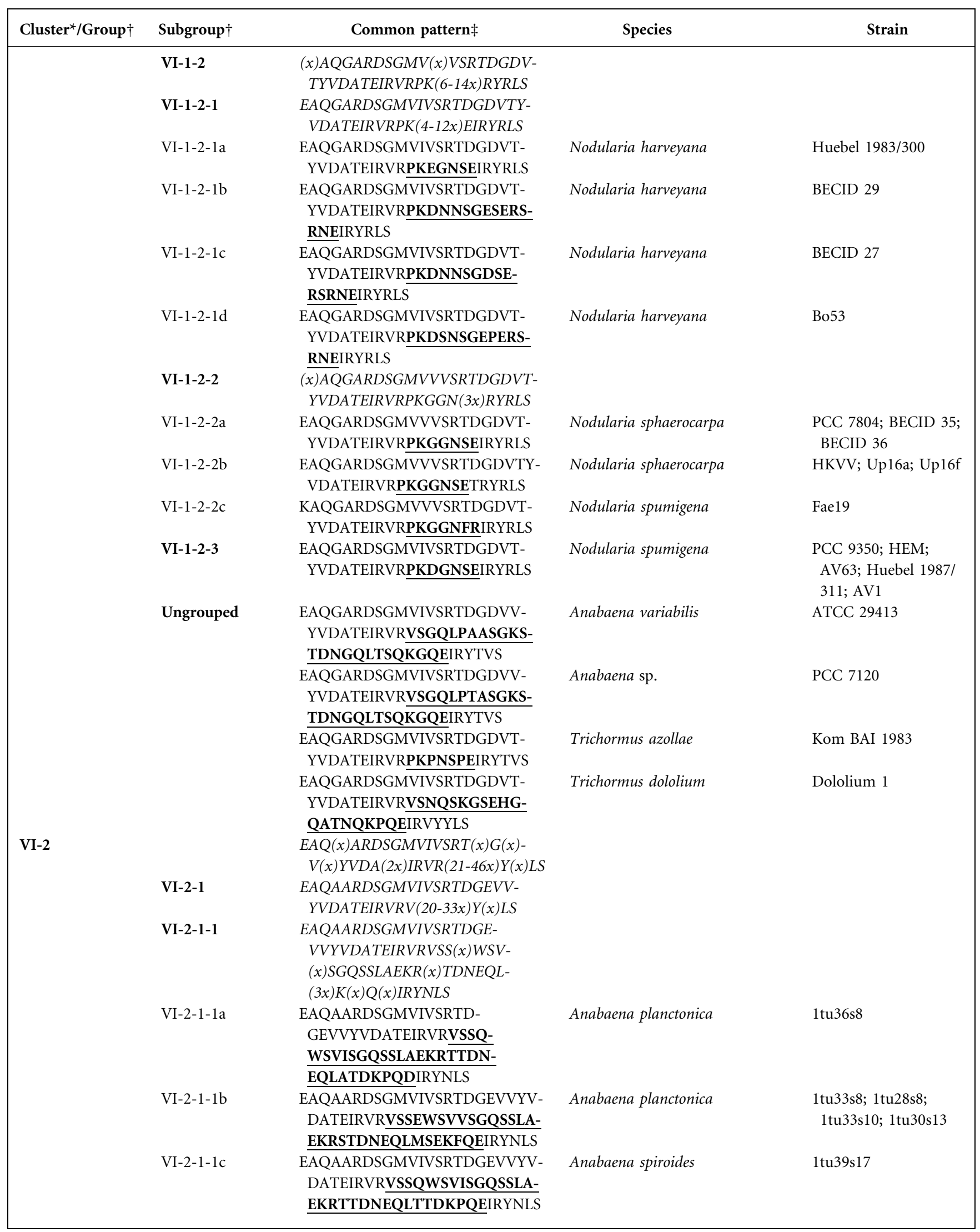


Table 1. cont.

\begin{tabular}{|c|c|c|c|c|}
\hline Cluster ${ }^{\star} /$ Group $\dagger$ & Subgroup $\dagger$ & Common pattern $\ddagger$ & Species & Strain \\
\hline & VI-2-1-2 & $\begin{array}{l}\text { EAQAARDSGMVIVSRTDGDVVYV- } \\
\text { DATEIRVRVGGQRLVVGDEEK- } \\
\text { TGDREQLRTDKPQELKYKLS } \\
\text { EAQAARDSGMVIVSRTDGDV(x)- } \\
\text { YVDATEIRVRASGQLSAASGS(6- } \\
\text { 7x)Q(x)IEKGQELKYKLS }\end{array}$ & Aphanizomenon flos-aquae & $\begin{array}{l}\text { 1tu26s2; 1tu29s19; } \\
1 \text { tu } 37 \mathrm{~s} 13\end{array}$ \\
\hline & VI-2-2-1 & $\begin{array}{l}\text { EAQAARDSGMVIVSRTDGD- } \\
\text { VVYVDATEIRVRASGQLSA- } \\
\text { ASGSQVIEKGQELKYKLS }\end{array}$ & Anabaena sp. & 90 \\
\hline & VI-2-2-2 & $\begin{array}{l}\text { EAQAARDSGMVIVSRTDGD- } \\
\text { VIYVDATEIRVRASGQLSA- } \\
\text { ASGSPQPIEKGQELKYKLS }\end{array}$ & Anabaena circinalis & 1 tu34s5 \\
\hline & VI-2-3 & $\begin{array}{l}\text { EAQGARDSGMVIVSRTDGD- } \\
\text { VVYVDAAEIRVRVREQEKED }(2- \\
3 x) R G Q D T E K N V K L G D T F(2 x)- \\
\text { SPRLPITSSSS }(x) P K E(x) R Y V L S\end{array}$ & & \\
\hline & VI-2-3-1 & $\begin{array}{l}\text { EAQGARDSGMVIVSRTDGDV- } \\
\text { VYVDAAEIRVRVREQEKEDT- } \\
\text { LTRGQGDTEKNVKLGDTFT- } \\
\text { ASPRLPITSSSSPPKEIRYVLS }\end{array}$ & Trichormus variabilis & HINDAK 2001/4 \\
\hline & VI-2-3-2 & $\begin{array}{l}\text { EAQGARDSGMVIVSRTDGDV- } \\
\text { VYVDAAEIRVRVREQEKEDH- } \\
\text { GRGQDTEKNVKLGDTFSPSPR- } \\
\text { LPITSSSSSPKEVRYVLS }\end{array}$ & Trichormus variabilis & GREIFSWALD \\
\hline & VI-2-4 & $\begin{array}{l}\text { EAQAARDSGMVIVSRTHGDVV- } \\
\text { YVDATEIRVRVSGQ }(x) S A A S G S- \\
\text { QVIEKGQEIRY }(x) L S\end{array}$ & & \\
\hline & VI-2-4-1 & $\begin{array}{l}\text { EAQAARDSGMVIVSRTHGDVVY- } \\
\text { VDATEIRVRVSGQLSAASGSQ- } \\
\text { VIEKGQEIRYNLS }\end{array}$ & Anabaena oscillarioides & BECID 22; BECID 32 \\
\hline & VI-2-4-2 & $\begin{array}{l}\text { EAQAARDSGMVIVSRTHGDVVY- } \\
\text { VDATEIRVRVSGQISAASGSQVI- } \\
\text { EKGQEIRYTLS }\end{array}$ & Anabaena cylindrica & XP6B \\
\hline & Ungrouped & $\begin{array}{l}\text { EAQGARDSGMVIVSRTDGDVVY- } \\
\text { VDAAQIRVRVRGDLSGVTGNLIA- } \\
\text { GKQHTNEQGQQVTDREIRYVLS }\end{array}$ & Anabaena oscillarioides & BO HINDAK 1984/43 \\
\hline & & $\begin{array}{l}\text { EAQGARDSGMVIVSRTDGDV- } \\
\text { VYVDAAEIRVRVREQTTDKTL- } \\
\text { TQSPASSKESPTGKPQEVTYYLS }\end{array}$ & Anabaena augstumalis & $\begin{array}{l}\text { SCHMIDKE } \\
\text { JAHNKE/4a }\end{array}$ \\
\hline & & $\begin{array}{l}\text { EAQAARDSGMVIVSRTDGEVV- } \\
\text { YVDATEIRVRVSGQSLLANQQ- } \\
\text { TTDKEQHAPEKPQEIKYTLS }\end{array}$ & Anabaena sp. & 1 tu34S7 \\
\hline & & $\begin{array}{l}\text { EAQAARDSGMVIVSRTDGEVVYV- } \\
\text { DATEIRVRVSSQWSIVSGQQTT- } \\
\text { DNEQQTTDKPQEIKYTLS }\end{array}$ & Aphanizomenon issatschenkoi & 0tu37S7 \\
\hline & & $\begin{array}{l}\text { EAQGARDSGMVIVSRTDGDVTY- } \\
\text { VDAAEIRVRVREPLTETNTQHP- } \\
\text { PKEVRYVLS }\end{array}$ & Anabaena sp. & PCC 7108 \\
\hline & Unclustered & $\begin{array}{l}\text { EAQAARDSGMVIVSRTEGIVTYA- } \\
\text { DANEIRVKVTGPEGHEKVGQE- } \\
\text { IQYILQ }\end{array}$ & Crocosphaera watsonii & WH8501 \\
\hline & & $\begin{array}{l}\text { EAQAARDSGMVIVSRTHGIVTY- } \\
\text { VDATEIRVQPHSPDNPAEKGE- } \\
\text { EIVYPIQ }\end{array}$ & Synechocystis sp. & PCC 6803 \\
\hline & & $\begin{array}{l}\text { EAQAARDSGMVILSQTNGVVSY- } \\
\text { VDANQIRVKTDNGPEITYTLQ }\end{array}$ & Thermosynechococcus elongatus & BP1 \\
\hline
\end{tabular}


Table 1. cont.

\begin{tabular}{|c|c|c|c|c|}
\hline Cluster $^{\star} /$ Group $^{\dagger}$ & Subgroup $\dagger$ & Common pattern $\ddagger$ & Species & Strain \\
\hline
\end{tabular}

${ }^{*}$ Clusters have been determined according to the $16 \mathrm{~S}$ rRNA gene sequence-based phylogenetic tree presented in Fig. 2, and specified into groups depending on their organization in $r p o B$ trees.

$\dagger$ Groups and subgroups have been determined based on signature sequence identity.

¥Indels are in shown in bold; signature sequences are underlined.

\$Strain NIES 843 has been reassigned to the species Microcystis aeruginosa.

Trichormus (Fig. 4b, c and d). In group VI-1, the Nostoc and Nodularia strains are separated into two monophyletic subgroups (VI-1-1 and VI-1-2) (Fig. 3c and d). Moreover, subgroups VI-1-2-1 and VI-1-2-3 include strains with the same species attribute, Nodularia harveyana and Nodularia spumigena, respectively. This shows that, in some cases, the signature can differentiate strains at the species level. However, some other subgroups contain two different species, e.g. subgroup VI-1-2-2b includes both Nodularia sphaerocarpa and Nodularia spumigena (Table 1 and Fig. $3 d)$. Although one cannot exclude that the mutation rate of this $r p o B$ region differs in some strains, this might result from a misleading species assignment.

Rajaniemi et al. (2005) published a partial tree from the same $r p o B$ gene sequence portion, but did not distinguish between groups VI-1 and VI-2, although groups A and B defined by these authors appear to perfectly correspond to the subgroups VI-2-1-1 and VI-2-1-2 identified in the present study (Fig. 4b and c; Table 1). In this example, even if the signature sequence comprises a small number of nucleotides, it provides the same resolution as longer sequences. The fact that strains belonging to the genera Anabaena, Aphanizomenon and Trichormus are not separated into discrete subgroups (Fig. 4c and d) supports the hypothesis that these cyanobacterial strains might belong to the same genus, within which several species can be distinguished, as discussed by Rajaniemi et al. (2005).

Interestingly, in cluster $\mathrm{V}$ (Table 1), RpoB signature sequences can be useful to identify groups first on the basis of pattern length and second on the basis of their specific amino acid sequence. For example, in cluster $\mathrm{V}$, the Oscillatoria strains present six and 40 aa indels. Notably, all the Planktothrix strains ( $P$. agardhii and $P$. rubescens) whose sequences have been determined in the present study fall within group V-2 with a longer indel, with the exception of strain PCC 9214 (Table 1). Thus, knowing that Planktothrix strains can be distinguished on the basis of the $r p o B$ signature sequence length, a simple PCR might be sufficient, as a primary screen, to identify subgroups to which particular strains belong. In contrast, the five Oscillatoria strains analysed in the present study are distributed in three subgroups, V-1-2, V-2-2 and V-2-3, that include either long or short sequences (Table 1). This observation suggests that a re-examination of the taxonomic position of Oscillatoria sp. strains PCC 8926, PCC 8927, PCC 8954, PCC 9018 and PCC 9631, as well as Planktothrix agardhii PCC 9214, using a polyphasic approach (Suda et al., 2002) is required to clearly establish if they belong to the genera Planktothrix or Oscillatoria.

\section{Concluding remarks}

The signatures of the rpoB sequences of cyanobacteria identified in this study that allow the identification of strains at a subgenus level even permit species separation for some taxa. These signature sequences might thus be particularly useful for the identification and classification of a large number of isolates, as well as for assessment of cyanobacterial biodiversity in natural microbial communities and for following the seasonal abundance of cyanobacteria in a given community over time. Generally, these $r p o B$ signatures may be used as a tool to change the current view of the classification of nostocacean strains, and possibly that of other cyanobacterial groups. The contribution of molecular typing provided by $r p o B$ and other housekeeping gene indels may well advance the resolution of specific cases in cyanobacterial taxonomy or provide an intermediate level of variability suited to various molecular typing applications, including DGGE and SSCP (Boutte et al., 2006; Dorigo et al., 2005).

\section{ACKNOWLEDGEMENTS}

We wish to thank the CAE (Centre d'Analyses Environnementales) of Veolia Environment, the Institut Pasteur and CNRS URA-2172 for funding this work. We are grateful to the CAE of Veolia Environment for providing a thesis fellowship to V.G., and to K. Delabre and F. Enguehard for constant support during this study. We express our gratitude to T. Rose for his advice on three-dimensional predictions and thank J. P. Rasmussen for helpful comments and his revision of the English during the preparation of this paper.

\section{REFERENCES}

Boutte, C., Grubisic, S., Balthasart, P. \& Wilmotte, A. (2006). Testing of primers for the study of cyanobacterial molecular diversity by DGGE. J Microbiol Methods 65, 542-550. 
Case, R. J., Boucher, Y., Dahllof, I., Holmstrom, C., Doolittle, W. F. \& Kjelleberg, S. (2007). Use of $16 \mathrm{~S}$ rRNA and $r p o B$ genes as molecular markers for microbial ecology studies. Appl Environ Microbiol 73, 278-288.

Castresana, J. (2000). Selection of conserved blocks from multiple alignments for their use in phylogenetic analysis. Mol Biol Evol 17, 540-552.

Dorigo, U., Volatier, L. \& Humbert, J. F. (2005). Molecular approaches to the assessment of biodiversity in aquatic microbial communities. Water Res 39, 2207-2218.

Giovannoni, S. J., Turner, S., Olsen, G. J., Barns, S., Lane, D. J. \& Pace, N. R. (1988). Evolutionary relationships among cyanobacteria and green chloroplasts. J Bacteriol 170, 3584-3592.

Greuter, W., McNeill, J., Barrie, F. R., Burdet, H. M., Demoulin, V., Filgueiras, T. S., Nicolson, D. H., Silva, P. C., Skog, J. E. \& other authors (2000). Regnum Vegetabile Volume 118; International Code of Botanical Nomenclature (Saint Louis Code). ISSN 0080-0694 / ISBN 387429-278-9.

Guindon, S. \& Gascuel, O. (2003). A simple, fast, and accurate algorithm to estimate large phylogenies by maximum likelihood. Syst Biol 52, 696-704.

Gupta, R. S. (1997). Protein phylogenies and signature sequences: evolutionary relationships within prokaryotes and between prokaryotes and eukaryotes. Antonie van Leeuwenhoek 72, 49-61.

Gupta, R. S. (1998). Protein phylogenies and signature sequences: A reappraisal of evolutionary relationships among archaebacteria, eubacteria, and eukaryotes. Microbiol Mol Biol Rev 62, 14351491.

Gupta, R. S. (2003). Evolutionary relationships among photosynthetic bacteria. Photosynth Res 76, 173-183.

Gupta, R. S. (2009). Protein signatures (molecular synapomorphies) that are distinctive characteristics of the major cyanobacterial clades. Int J Syst Evol Microbiol 59, 2510-2526.

Hasegawa, M., Kishino, H. \& Yanp, T. (1985). Dating of the humanape splitting by a molecular clock of mitochondrial DNA. J Mol Evol 22, 160-174.

Honda, D., Yokota, A. \& Sugiyama, J. (1999). Detection of seven major evolutionary lineages in cyanobacteria based on the $16 \mathrm{~S}$ rRNA gene sequence analysis with new sequences of five marine Synechococcus strains. J Mol Evol 48, 723-739.

Hong, S. K., Kim, B. J., Yun, Y. J., Lee, K. H., Kim, E. C., Park, E. M., Park, Y. G., Bai, G. H. \& Kook, Y. H. (2004). Identification of Mycobacterium tuberculosis by PCR-linked reverse hybridization using specific $r p o B$ oligonucleotide probes. J Microbiol Methods 59, 71-79.

Ishida, T., Watanabe, M. M., Sugiyama, J. \& Yokota, A. (2001). Evidence for polyphyletic origin of the members of the orders of Oscillatoriales and Pleurocapsales as determined by $16 \mathrm{~S}$ rDNA analysis. FEMS Microbiol Lett 201, 79-82.

Iteman, I., Rippka, R., Tandeau de Marsac, N. \& Herdman, M. (2002). rDNA analyses of planktonic heterocystous cyanobacteria, including members of the genera Anabaenopsis and Cyanospira. Microbiology 148, 481-496.

Jeanmougin, F., Thompson, J. D., Gouy, M., Higgins, D. G. \& Gibson, T. J. (1998). Multiple sequence alignment with CLUSTAL_X. Trends Biochem Sci 23, 403-405.

Kuznedelov, K., Korzheva, N., Mustaev, A. \& Severinov, K. (2002). Structure-based analysis of RNA polymerase function: the largest subunit's rudder contributes critically to elongation complex stability and is not involved in the maintenance of RNA-DNA hybrid length. EMBO J 21, 1369-1378.
Lapage, S. P., Sneath, P. H. A., Lessel, E. F., Skerman, V. B. D., Seeliger, H. P. R. \& Clarck, W. A. (1992). International Code of Nomenclature of Bacteria (1990 revision). Washington, D.C.: American Society for Microbiology.

Nicholas, K. B., Nicholas, H. B. \& Deerfield, D. W. (1997). GeneDoc: analysis and visualization of genetic variation. EMBNET News 4, $1-4$.

Oren, A. (2004). A proposal for further integration of the cyanobacteria under the Bacteriological Code. Int J Syst Evol Microbiol 54, 1895-1902.

Rajaniemi, P., Hrouzek, P., Kastovska, K., Willame, R., Rantala, A., Hoffmann, L., Komarek, J. \& Sivonen, K. (2005). Phylogenetic and morphological evaluation of the genera Anabaena, Aphanizomenon, Trichormus and Nostoc (Nostocales, Cyanobacteria). Int J Syst Evol Microbiol 55, 11-26.

Rasmussen, B., Fletcher, I. R., Brocks, J. J. \& Kilburn, M. R. (2008). Reassessing the first appearance of eukaryotes and cyanobacteria. Nature 455, 1101-1104.

Rippka, R. (1988). Isolation and purification of cyanobacteria. Methods Enzymol 167, 3-27.

Salerno, A., Deletoile, A., Lefevre, M., Ciznar, I., Krovacek, K., Grimont, P. \& Brisse, S. (2007). Recombining population structure of Plesiomonas shigelloides (Enterobacteriaceae) revealed by multilocus sequence typing. J Bacteriol 189, 7808-7818.

Sayle, R. A. \& Milner-White, E. J. (1995). RASMOL: biomolecular graphics for all. Trends Biochem Sci 20, 374.

Stanier, R. Y., Sistrom, W. R., Hansen, T. A., Whitton, B. A., Castenholz, R. W., Pfennig, N., Gorlenko, V. N., Kondratieva, E. N., Eimhjellen, K. E. \& other authors (1978). Proposal to place the nomenclature of the cyanobacteria (blue-green algae) under the rules of the International Code of Nomenclature of Bacteria. Int J Syst Bacteriol 28, 335-336.

Suda, S., Watanabe, M. M., Otsuka, S., Mahakahant, A., Yongmanitchai, W., Nopartnaraporn, N., Liu, Y. \& Day, J. G. (2002). Taxonomic revision of water-bloom-forming species of oscillatorioid cyanobacteria. Int J Syst Evol Microbiol 52, 1577-1595.

Tamura, K., Dudley, J., Nei, M. \& Kumar, S. (2007). MEGA4: Molecular Evolutionary Genetics Analysis (MEGA) software version 4.0. Mol Biol Evol 24, 1596-1599.

Tanabe, Y., Kasai, F. \& Watanabe, M. M. (2007). Multilocus sequence typing (MLST) reveals high genetic diversity and clonal population structure of the toxic cyanobacterium Microcystis aeruginosa. Microbiology 153, 3695-3703.

Trüper, H. G. (1986). International Committee on Systematic Bacteriology Subcommittee on the Taxonomy of Phototrophic Bacteria. Minutes of the Discussion Workshop: Taxonomy of Cyanobacteria, 17 to 19 June 1985, Paris, France. Int J Syst Bacteriol 36, 114-115.

Turner, S., Pryer, K. M., Miao, V. P. W. \& Palmer, J. D. (1999). Investigating deep phylogenetic relationships among cyanobacteria and plastids by small subunit rRNA sequence analysis. J Eukaryot Microbiol 46, 327-338.

Volokhov, D. V., Neverov, A. A., George, J., Kong, H., Liu, S. X., Anderson, C., Davidson, M. K. \& Chizhikov, V. (2007). Genetic analysis of housekeeping genes of members of the genus Acholeplasma: Phylogeny and complementary molecular markers to the 16S rRNA gene. Mol Phylogenet Evol 44, 699-710.

Wilmotte, A. \& Herdman, M. (2001). Phylogenetic relationships among the cyanobacteria based on 16S rRNA sequences. In Bergey's Manual of Systematic Bacteriology, 2nd edn, vol. 1, pp. 487493. Edited by D. R. Boone \& R. W. Castenholz. New York: Springer. 
Zhang, J. \& Madden, T. L. (1997). PowerBLAST: a new network BLAST application for interactive or automated sequence analysis and annotation. Genome Res 7, 649-656.
Zhang, Z., Schwartz, S., Wagner, L. \& Miller, W. (2000). A greedy algorithm for aligning DNA sequences. J Comput Biol 7, 203-214. 